\section{REFERENCES}

Barrett, J. (1959). Nature, Lond., 183, 1185.

Barrett, J. \& Clezy, P. (1959). Nature, Lond., 184, 1988.

Bowden, K., Heilbron, I. M., Jones, E. R. H. \& Weedon, B. C. L. (1946). J. chem. Soc. p. 39.

Chu, T. C., Green, A. A. \& Chu, E. J. (1951). J. biol. Chem. $190,643$.

Clezy, P. \& Barrett, J. (1961). Biochem. J. 78, 246.

Corwin, A. H. \& Wei, P. (1962). J. org. Chem. 27, 4285.

Falk, J. E. (1961). J. Chromat. 5, 277.

Granick, S. (1961). J. biol. Chem. 236, 1168.

Griffiths, M. (1962). J. gen. Microbiol. 27, 427.

Holt, A. S., Hughes, D. W., Kende, H. J. \& Purdie, J. W.

(1963). Plant \& Cell Physiol., Tokyo, 4, 49.
Jones, O. T. G. $(1963 a)$. Biochem. J. 86, 429.

Jones, O. T. G. $(1963 b)$. Biochem. J. 88, 335.

Jones, O. T. G. (1963c). Biochem. J. 89, 182.

Morell, D. B., Barrett, J. \& Clezy, P. S. (1961). Biochem. J. 78, 793.

Sistrom, W. R., Griffiths, M. \& Stanier, R. Y. (1956). J. cell. comp. Physiol. 48, 459.

Smith, J. H. C. \& Benitez, A. (1955). In Modern Methods of Plant Analysis, vol. 4, p. 142. Ed. by Paech, K. \& Tracey, M. V. Berlin: Springer-Verlag.

Stanier, R. Y. \& Smith, J. H. C. (1960). Biochim. biophys. Acta, 41, 478.

Stern, A. \& Pruckner, F. (1939). Hoppe-Seyl. Z. A, 185, 140.

Willstätter, R. \& Mieg, W. (1906). Liebigs Ann. 350, 1.

Biochem. J. (1964), 91, 576

\title{
Metabolism of Amino Acids in the Lens
}

\author{
BY S. G. WALEY \\ Nuffield Laboratory of Ophthalmology, University of Oxford
}

(Received 1 November 1963)

The metabolism of amino acids in the lens has not been widely studied. This applies to the conversion of amino acids into other low-molecularweight compounds, and also, to a lesser extent, to the incorporation of amino acids into proteins. Previous work on the metabolism of glycine (Merriam \& Kinsey, 1950; Kinsey \& Merriam, 1950) and of other amino acids (Dardenne \& Kirsten, 1962) has been confined to rabbit lens; cattle lens was used in the work to be described since this was the species used previously in investigations of the metabolism of peptides (Cliffe \& Waley, 1958) and of protein breakdown (Waley \& van Heyningen, 1962; van Heyningen \& Waley, 1963). Intact ox lenses have been incubated in solutions containing radioactive glycine (a metabolically active amino acid) and radioactive valine (a relatively unreactive amino acid), and the products have been separated by chromatography and electrophoresis, and detected by radioautography, in order to establish the main metabolic pathways involving these amino acids.

The kinetics of the incorporation of a mixture of radioactive amino acids into the proteins of ox lens has been studied in an attempt to assess the relative importance of turnover and net synthesis. The results suggest that the synthesis of proteins is more rapid than can be accounted for by growth, so that turnover is the main process responsible for the incorporation. An (unsuccessful) attempt was also made to detect low-molecular-weight intermediates in the synthesis of proteins.

\section{EXPERIMENTAL}

\section{Materials}

The radioactive amino acids (The Radiochemical Centre, Amersham, Bucks.) used were: $\left[2 \cdot{ }^{14} \mathrm{C}\right]$ glycine, specific activity $5.69 \mu \mathrm{c} / \mu$ mole, uniformly labelled $\mathrm{L}-\left[\mathrm{U} \cdot{ }^{14} \mathrm{C}\right]$ valine, specific activity $25.9 \mu \mathrm{c} / \mu \mathrm{mole}$, and a hydrolysate (specific activity about $200 \mu \mathrm{c} / \mathrm{mg}$.) of protein from Chlorella vulgaris grown on ${ }^{14} \mathrm{CO}_{2}$. There were five radioactive contaminants in the glycine, each containing about $0.3 \%$ of the total radioactivity; the contaminants were detected by electrophoresis and chromatography on paper of about $0.5 \mu \mathrm{c}$. The purity of the valine was comparable.

\section{Methods}

Media for incubations. Medium A contained (in $100 \mathrm{ml}$.): $0.25 \mathrm{ml}$. of $6.9 \%(\mathrm{w} / \mathrm{v}) \mathrm{MgSO}_{4}, 7 \mathrm{H}_{2} \mathrm{O}, 0.5 \mathrm{ml}$. of $5.1 \%$ (w/v) $\mathrm{CaCl}_{2}, 1 \mathrm{ml}$. of $4.1 \%$ (w/v) $\mathrm{KCl}, 0.06 \mathrm{ml}$. of $\mathrm{M}$ potassium phosphate buffer, $\mathrm{pH} 7 \cdot 4,10 \mathrm{ml}$. of $6 \cdot 13 \%$ (w/v) $\mathrm{NaCl}, 10 \mathrm{ml}$. of $2.52 \%$ (w/v) $\mathrm{NaHCO}_{3}$ (gassed with $\left.\mathrm{CO}_{2}\right), 0.1 \mathrm{~g}$. of glucose, $0.01 \mathrm{~g}$. of penicillin, $0.01 \mathrm{~g}$. of streptomycin and $0.01 \mathrm{~g}$. of phenol red. Medium B contained, in $7 \mathrm{ml} .: 55 \mathrm{mg}$. of ' $\mathrm{TC}$ medium dried 199' (Difco Laboratories, Detroit, Mich., U.S.A.), $1.0 \mathrm{ml}$. of $2.5 \%$ (w/v) $\mathrm{NaHCO}_{3}, 0.7 \mathrm{mg}$. of penicillin, $0.7 \mathrm{mg}$. of streptomycin and $7 \mathrm{mg}$. of glucose. A volume of $5 \mathrm{ml}$. of medium A or of medium $B$ was used for each incubation. The incubation tubes were gassed with air- $\mathrm{CO}_{2}(95: 5)$ for $10 \mathrm{~min}$., and then stoppered; they were rocked gently during the incubations, which were carried out at $34^{\circ}$.

Gel filtration. This was carried out on columns, $2 \cdot 7 \mathrm{~cm} . \times$ $15 \mathrm{~cm}$. long or $2.75 \mathrm{~cm} . \times 30 \mathrm{~cm}$. long, of Sephadex G-25 (medium grade) at room temperature. The columns were equilibrated with the buffers used for elution, usually either 


\section{Table 1. Incorporation of $\left[{ }^{2-{ }^{14}} \mathrm{C}\right]$ glycine into the proteins of the cortex and nucleus of ox lens}

After incubation for $23 \mathrm{hr}$. the lens was divided into the outer portion (cortex) and the inner portion (nucleus); the radioactivity in aq. formic acid extracts of each portion was determined, and protein then isolated as described in the text. The proteins were counted as infinitely thick layers. From the relation: sp. activity at infinite thickness (counts $/ \mathrm{sec} . / 4 \mathrm{~cm} .{ }^{2}$ ) $=18.5 \times \mathrm{sp}$. activity at infinite thinness (counts/sec./mg.), determined from 12 samples of labelled protein, and the amount of protein (approx. $33 \%$ of the wet wt.), the total radioactivity in the protein of each part of the lens was calculated. This is given as a percentage of the total radioactivity, in each part of the lens, in the last column.

$\begin{array}{lcccc} & \begin{array}{c}\text { Radioactivity in } \\ \text { clarified formic } \\ \text { acid extract }\end{array} & \begin{array}{c}\text { Sp. activity of } \\ \text { first trichloroacetic }\end{array} & \begin{array}{c}\text { Sp. activity of } \\ \text { second trichloroacetic }\end{array} & \begin{array}{c}\text { Extent of } \\ \text { acid ppt. }\end{array} \\ \text { Portion } & \text { (counts/sec.) } & \left.\text { (counts/sec./4 cm. } .^{2}\right) & \text { (counts/sec./4 cm. }^{2} \text { ) } & (\%) \\ \text { Cortex } & 8540 & 18 \cdot 6 & 16 \cdot 6 & 4 \cdot 3 \\ \text { Nucleus } & 930 & 2 \cdot 3 & 0 \cdot 16 & 0.2\end{array}$

triethylamine carbonate (prepared by passing $\mathrm{CO}_{2}$ into $1.39 \mathrm{ml}$. of triethylamine in $500 \mathrm{ml}$. of water until the solution was no longer alkaline to phenolphthalein but was still alkaline to bromothymol blue, i.e. pH about 8), or $5 \%$ $(\nabla / v)$ formic acid. To prevent bacterial growth $\mathrm{CHCl}_{3}$ was added to the triethylamine carbonate buffer, and the columns were stored in the cold room. The separation of glycine, and of valine, from lens protein was tested by adding the radioactive amino acids to (unincubated) lens extracts, and carrying out gel filtration; portions of the fractions that contained protein were counted and found to have little or no radioactivity. The formic acid was preferred as an eluting agent for experiments in which radioactive glycine was used because it gave better separation of glutathione from proteins. Glutathione is partially excluded from the interior of the gel particles (Porath, 1960).

Isolation of radioactive protein. In the procedure used, unless otherwise stated, the lens and a little sand were ground with $10 \mathrm{ml}$. of $5 \%(v / v)$ formic acid, and the mixture clarified by centrifuging and fractionated by gel filtration on a column equilibrated, and eluted, with $5 \%$ $(v / v)$ formic acid. Protein was detected in the eluate by adding $0.5 \mathrm{ml}$. of a fraction to $7 \mathrm{ml}$. of $1.25 \%(\mathrm{w} / \mathrm{v})$ trichloroacetic acid and measuring the turbidity. The fractions that contained protein were united and treated with 0.33 vol. of $30 \%(w / v)$ trichloroacetic acid. The protein was separated by centrifuging and washed three times with $10 \%(w / v)$ trichloroacetic acid, once with acetone and once with ether, and dried in air.

Detection and measurement of radioactivity. An endwindow Geiger-Müller tube was used. Counting at 'infinite thinness' was carried out by adding about $0.05 \mathrm{ml}$. of solution to a $4 \mathrm{~cm}^{2}$ planchet, superimposing a disk of lens tissue and drying under an infrared lamp; the efficiency was about $4 \%$. Protein was counted as an infinitely thick layer, or as a thin layer from a solution in formic acid; corrections for self-absorption were made where necessary (Maramatsu \& Busch, 1962). Sufficient counts were recorded for the standard error to be less than $5 \%$. Radioautography was carried out with Kodak Royal Blue X-ray films, usually for 2 weeks.

Electrophoresis and chromatography on paper. Samples $(20 \mu \mathrm{l}$.) of the low-molecular-weight fractions (after concentration) were applied $5 \mathrm{~cm}$. from the anode end of a strip of Whatman no. 3 paper $25 \mathrm{~cm}$. long, and electrophoresis in formic acid-acetic acid-water $(125 \mathrm{ml}$. of $90 \%, w / v$, formic acid and $375 \mathrm{ml}$. of acetic acid in 2.51 .) was carried out for $2 \mathrm{hr}$. at $400 \mathrm{v}$ in a ridge-pole apparatus. The dried strip was then sewn (with a zig-zag stitch; Naughton \& Hagopian, 1962) into a full-length sheet of no. 3 paper, so that the spot where the sample was applied was $10 \mathrm{~cm}$. from the top of the paper. Chromatography was carried out (downwards) in butan-1-ol-acetic acid-water $(40: 9: 20$, by vol.), usually for $16 \mathrm{hr}$.

Electrophoresis at pH 4 (pyridine acetate buffer; Grassmann, Hannig \& Plöckl, 1955), followed by chromatography in butan-1-ol-acetic acid-water-pyridine (15:3: 12:10, by vol.) has also been used.

\section{RESULTS}

\section{Incorporation of amino acids into proteins of the lens}

Incorporation of glycine into the proteins of the cortex and nucleus of ox lens. An ox lens was incubated for $23 \mathrm{hr}$. in medium A containing $5 \mu \mathrm{C}$ of $\left[2-{ }^{14} \mathrm{C}\right]$ glycine. The cortex $(1 \cdot 23 \mathrm{~g}$.) and nucleus $(0.8 \mathrm{~g}$.$) were separated by dissection, and each part$ was ground with $5 \%(\mathrm{v} / \mathrm{v})$ formic acid. Portions of each extract were taken for counting, and the remainder was fractionated by gel filtration and the protein isolated. After being counted (first trichloroacetic acid precipitate, Table 1), the protein was dissolved in $3 \mathrm{ml}$. of $\mathrm{N}$-sodium hydroxide; $1 \mathrm{hr}$. later the protein was precipitated with $4 \mathrm{ml}$. of $30 \%(w / v)$ trichloroacetic acid and washed, dried and again counted at infinite thickness (second trichloroacetic acid precipitate, Table 1). The nucleus contained considerably less radioactivity than the cortex, and the difference in the specific activity of the proteins was even more marked. This difference is probably not mainly caused by slow penetration of the amino acid into the nucleus of the lens, since the extents of incorporation (which are based on the total radioactivity in the cortex and nucleus) differ. The specific activity of the first trichloroacetic acid precipitate from the nucleus was much decreased by treatment with alkali and reprecipitation.

Incorporation of glycine into $\alpha$ - and $\beta$-crystallins of ox lens. The specific activities of the proteins 
precipitated at $\mathrm{pH} 5$ ( $\alpha$-crystallin), and soluble at pH 5 ( $\beta$-crystallin), were comparable at both times $(2 \mathrm{hr}$. and $22.5 \mathrm{hr}$.) of incubation (Table 2). The purified neutral proteinase from ox lens cortex attacks $\alpha$-crystallin but not $\beta$-crystallin (van Heyningen \& Waley, 1963), but this experiment suggests that there is no marked difference in the (mean) rate of synthesis in the proteins comprising these two fractions.

Inhibition of incorporation of valine into calf lens protein by puromycin. For these experiments the radioactive valine was purified. Since paper electrophoresis at $\mathrm{pH} 4$ showed that most of the contaminants were acidic, the valine $(100 \mu \mathrm{C})$ was purified by using the anion-exchange resin, Dowex 1 (acetate form; X4). A pair of calf lenses were incubated, each in $5 \mathrm{ml}$. of medium B. Puromycin dihydrochloride (concn. in medium, $0.1 \mathrm{~mm}$ ) was present in one tube, and about $40 \mu \mathrm{C}$ of the purified valine was added to each tube. After incubation for $20 \mathrm{hr}$. each lens was ground under $4 \mathrm{ml}$. of redistilled $90 \%(\mathrm{w} / \mathrm{v})$ phenol and $4 \mathrm{ml}$. of water, and the layers were separated after centrifuging. The protein was isolated from the phenol layers as follows (the aqueous layer, fraction $A$, was kept for the work to be described in the next section). The phenol was removed by adding water and evaporating several times and the residue in $3 \mathrm{ml}$. of $\mathrm{N}$ sodium hydroxide was kept for $1 \mathrm{hr}$. at room temperature. Protein was precipitated with $4 \mathrm{ml}$. of $30 \%(\mathrm{w} / \mathrm{v})$ trichloroacetic acid, and washed first with $10 \%(\mathrm{w} / \mathrm{v})$ trichloroacetic acid (fraction B) and then with $5 \%(\mathrm{w} / \mathrm{v})$ of valine in $10 \%(\mathrm{w} / \mathrm{v})$ trichloroacetic acid, and finally with acetone and with ether. The results (Table 3) show that incorporation was markedly affected by the presence of puromycin in the incubation medium.

Attempted isolation of radioactive peptides after incubation of calf lens with valine. The experiment just described was carried out under conditions that might have led to the accumulation of intermediates in protein synthesis. Attempts to isolate such intermediates from various fractions are now described.

The $10 \%(\mathrm{w} / \mathrm{v})$ trichloroacetic acid washings (fraction B) of the proteins contained appreciable radioactivity (5300 counts/sec. in the experiment with added puromycin, 3300 counts/sec. in the control experiment). Amino compounds were isolated from the solution by adsorption on Dowex 50 ( $\mathrm{H}^{+}$form), and elution with aqueous triethylamine (nearly all the radioactivity was thus recovered). Analysis by electrophoresis, followed by chromatography and radioautography, showed that the only appreciably radioactive substance was valine. Valine is partly extracted by phenol, and any valylRNA would be hydrolysed by the treatment with N-sodium hydroxide. Any peptides of valine extracted by phenol should have been detected, and, if in the form of peptidyl-RNA, they should also have been hydrolysed by alkali to the free peptides.

The aqueous layers (fraction A), after the extraction of the protein by phenol, were submitted to gel filtration in $1 \%$ acetic acid. The highmolecular-weight fractions contained very little radioactivity, and so were not further examined. The low-molecular-weight fractions (which contained about $10^{4}$ counts/sec.) were concentrated and analysed by electrophoresis and chromatography. After radioautography, about 12 relatively fast spots were present, in addition to a very strong valine spot, containing $98-99 \%$ of the radioactivity in the solution. Most of the spots were common to both the control experiment and the one with added puromycin. One spot has been identified as due to glutamic acid. Another spot contained material that liberated radioactive valine on acid hydrolysis. This material (which, from its electrophoretic mobility, had an amino group) might thus be a peptide of valine; its chromatographic mobility is consistent with the structure $\gamma$-Glu-Val-Gly. The possibility that this peptide

\section{Table 2. Incorporation of glycine into $\alpha$ - and $\beta$-crystallins of ox lens}

The lens was incubated in medium A containing $5 \mu \mathrm{C}$ of $\left[2 .{ }^{14} \mathrm{C}\right]$ glycine, the cortex was extracted and the protein fractions were isolated (Waley \& van Heyningen, 1962). The $\alpha$-crystallin was dissolved in water by the addition of $\mathrm{NaHCO}_{3}$, submitted to gel filtration, and the protein isolated by precipitation with trichloroacetic acid. The $\beta$ crystallin was treated similarly. In the $(22.5 \mathrm{hr}$.) second experiment, $\alpha_{2}$-crystallin was isolated with $13 \%(w / v)$ ethanol (Waley \& van Heyningen, 1962) and had the same specific activity as $\alpha_{1}$-crystallin; in the first $(2 \mathrm{hr}$.) experiment, protein corresponding to both $\alpha_{1}$-crystallin and $\alpha_{2}$ crystallin was precipitated together by $13 \%(w / v)$ ethanol at $\mathrm{pH}$. The proteins were counted as infinitely thick layers.

\begin{tabular}{ccc}
$\begin{array}{c}\text { Time of } \\
\text { incubation } \\
(\text { hr.) }\end{array}$ & \multicolumn{2}{c}{$\begin{array}{c}\text { Sp. activities } \\
\text { (counts/sec./1.8 cm. }{ }^{2} \text { ) }\end{array}$} \\
& $\alpha$-Crystallin & $\beta$-Crystallin \\
22.5 & 0.59 & 0.80 \\
& $7 \cdot 24$ & $9 \cdot 27$
\end{tabular}

Table 3. Effect of puromycin on incorporation of valine into calf lens protein

Calf lenses were incubated with radioactive valine in the presence and absence of puromycin (see text). The proteins were counted as infinitely thick layers.

$\begin{array}{ccc}\begin{array}{c}\text { Concn. of } \\ \text { puromycin } \\ \text { in medium }\end{array} & \begin{array}{c}\text { Sp. activity } \\ \text { of protein } \\ (\mathrm{mM})\end{array} & \begin{array}{c}\text { Inhibition } \\ \left.\text { (counts/sec./4 cm. }{ }^{2}\right)\end{array} \\ \begin{array}{ccc}(\%) \\ 0.1\end{array} & 438 & 0 \\ 0.1 & 70 & 84\end{array}$


might be one of the glutathione analogues in the lens has been noted previously (Waley, 1956; Cliffe \& Waley, 1958). However, this substance only contained about $0.1 \%$ of the radioactivity present as free valine, and this amount was too small for further study. If the specific activity of this material were comparable with that of the valine in the incubation medium (about $10^{4}$ counts/sec./ $\mu$ mole) then the amount of the material was only about $0.1 \mu$ mole.

Extraction of proteins with hot aqueous ethanol has been used to isolate peptides from microorganisms (Turba \& Esser, 1955) and so the protein (from an earlier experiment) was extracted three times with boiling $60 \%(\mathrm{v} / \mathrm{v})$ ethanol. The only radioactive material extracted was free valine (and some protein).

Kinetics of incorporation of amino acids into lens protein. In these attempts to estimate the turnover rate the proteins of the lens were not fractionated, but a mixture of radioactive amino acids was used so that any effects of a particularly metabolically labile protein of unusual amino acid composition on the incorporation would be minimized. Ox lenses were incubated for varying times in medium $B$ containing $5 \mu \mathrm{C}$ of a mixture of radioactive amino acids (hydrolysate of Chlorella proteins; see Materials section). Lenses from different animals had to be used, as each lens supplied only one point in the time-curve. The proteins were isolated by gel filtration in aqueous form in acid, and their specific activities determined at 'infinite' thinness. After it had been found on several occasions that the specific activities of the proteins were not appreciably changed by dissolution in alkali and reprecipitation with trichloroacetic acid, this step was omitted. The results are shown in Fig. 1.

The radioactivity of the incubation medium was determined at intervals during the incubations. The radioactivity in the amino acids in the lens

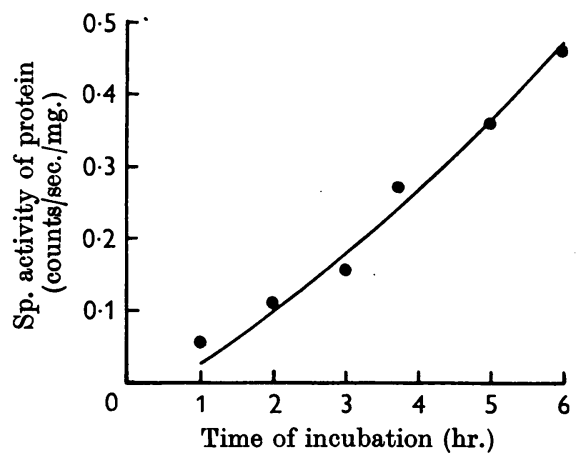

Fig. 1. Incorporation of radioactive amino acids into ox lens protein. Experimental values; the curve was calculated as described in the text. was then estimated as: (radioactivity lost from the incubation medium) - (radioactivity in the protein); the latter was less than $10 \%$ of the radioactivity in the amino acids. (Metabolic interconversions should not seriously affect the calculation, since much of the radioactivity was in the form of amino acids which are probably not rapidly metabolized in the lens, and conversions of one amino acid into another should not affect the results greatly.) An approximate value for the total amino acids in ox lens was taken as $2 \mathrm{mg}$., based on determinations of the amino compounds (about $40 \mu \mathrm{moles} / \mathrm{lens}$ ), and allowing for the presence of glutathione and of ophthalmic acid (Cliffe \& Waley, 1958). Hence the specific activity of the amino acids in the lens $\left(S_{A}\right)$ was estimated. This increased experimentally with the time of incubation $(t)$, and, as found in other instances (Helmreich \& Kipnis, 1962), fitted the curve:

$$
S_{\mathrm{A}}=A\left(1-e^{-k t}\right)
$$

From a logarithmic plot (Guggenheim, 1926), the values of $k$ and $A$ were $0.28 \mathrm{hr}^{-1}$ and 1690 counts/ sec./mg. respectively.

The simplest equation relating the specific activity $(S)$ of protein to that of the amino acids $\left(S_{\mathrm{A}}\right)$ is (Reiner, 1953, 1963):

$$
\mathrm{d} S / \mathrm{d} t=\lambda\left(S_{\mathrm{A}}-S\right)
$$

The significance of the parameter $\lambda$ when applied to a mixture of proteins is considered in the Discussion. In the present experiments, $S_{\mathbf{A}}$ was of the order 1000 counts/sec./mg., and $S$ was less than 1 count/sec./mg.; hence $S$ is negligible compared with $S_{\mathrm{A}}$, and $\mathrm{d} S / \mathrm{d} t=\lambda S_{\mathrm{A}}$. The variation of the specific activity of the protein with time is then given by:

$$
S=\lambda \int_{0}^{t} S_{\mathrm{A}} \mathrm{d} t
$$

Integration of equation (1) gives:

$$
\int_{0}^{t} S_{\mathrm{A}} \mathrm{d} t=A t-S_{\mathrm{A}} / k
$$

and hence:

$$
S=\lambda\left(A t-S_{\mathbf{A}} / k\right)
$$

The curve in Fig. 1 was calculated from equation (3) with a value for $\lambda$ of $8.4 \times 10^{-5} \mathrm{hr}^{-1}$; there is reasonable agreement with the experimental points, considering the crudity of the assumptions, which include one value $(k)$ for the transport of the different amino acids.

\section{Conversion of amino acids into low-molecular-weight products}

Catabolism of valine. Ox lens was incubated in medium A containing $5 \mu \mathrm{C}$ of uniformly labelled L-valine for $20 \mathrm{hr}$. (a parallel experiment in medium $B$ gave qualitatively similar results). The 
low-molecular-weight fraction was isolated by gel filtration in triethylamine carbonate buffer. The dry matter from this fraction was extracted with $0.05 \mathrm{ml}$. of water, and $0.02 \mathrm{ml}$. submitted to electrophoresis followed by chromatography. Radioautography was then carried out for 6 weeks. There was a very strong valine spot, and many fainter spots. Two of the stronger of these coincided with glutamic acid, and with GSSG, whose positions were shown by development with ninhydrin (and known by reference to the map prepared with markers). About $93 \%$ of the radioactivity was present as valine, and about $2 \%$ (each) as glutamic acid and as GSSG. Glutamic acid was also obtained in the experiment described above with calf lens, in which the radioactive valine was purified. Here the spot suspected of being glutamic acid was eluted from paper, and the eluate mixed with $5 \mu \mathrm{l}$. of a $10 \mathrm{~mm}$ solution of authentic glutamic acid. The solution was evaporated, and the residue dissolved in water and submitted to paper electrophoresis at $\mathrm{pH} 4$ for $6.5 \mathrm{hr}$. at $8 \mathrm{v} / \mathrm{cm}$. After radioautography, the acidic radioactive spot coincided with the ninhydrin-positive spot, which had travelled to the same position as authentic glutamic acid.

The other radioactive spots have not been identified, but it is not surprising that there should be several as the conversion of valine into glutamic acid involves many steps.

Metabolism of glycine. Four ox lenses were incubated, each in $5 \mathrm{ml}$. of medium A containing $5 \mu \mathrm{C}$ of $\left[2-{ }^{14} \mathrm{C}\right]$ glycine, for $23 \mathrm{hr}$. The lenses were then ground with $35 \mathrm{ml}$. of $10 \%(\mathrm{w} / \mathrm{v})$ trichloroacetic acid, the mixture was centrifuged and the supernatant freed from trichloroacetic acid by extraction with $5 \%(\mathrm{v} / \mathrm{v}) \quad N$-methyldioctylamine in chloroform. The aqueous layer was extracted three times with chloroform, concentrated to dryness under reduced pressure and the residue dissolved in $0.4 \mathrm{ml}$. of water. Electrophoresis, chromatography and radioautography showed that the main radioactive compounds were glycine, glutathione and serine. The glutathione was present both as GSH and as GSSG and the GSH spot covered a relatively large area. Both GSH and GSSG were oxidized to the sulphonic acid $\left(\mathrm{GSO}_{3} \mathrm{H}\right)$, which has a low mobility in electrophoresis and in chromatography (Waley, 1956). The oxidized material was analysed by electrophoresis, followed by chromatography, both in the standard system, and the pH 4 butanol-acetic acid-water-pyridine system. The distribution of radioactivity in the main compounds is shown in Table 4.

The cortex and the nucleus from the experiment described in Table 1 were separately studied. The distribution of radioactivity in the cortex was similar to that in Table 4; in the nucleus, there was relatively less radioactivity in glutathione. Also an incubation (for $5 \mathrm{hr}$. at $34^{\circ}$ ) of a brei from $1 \mathrm{~g}$. of ground lens cortex with $5 \mu \mathrm{l}$. of water containing $1 \cdot 25 \mu \mathrm{C}$ of $\left[2{ }^{14} \mathrm{C}\right]$ glycine gave a qualitatively similar pattern to that obtained from the incubation of intact lens.

Several unidentified radioactive compounds were formed from glycine. Attempts to identify these compounds have met with only limited success. The low-molecular-weight compounds were fractionated by passing the extract through a cation-exchange resin (Dowex $50 ; \mathrm{H}^{+}$form) to remove amino compounds, followed by anionexchange resin (Dowex 1; acetate form). Acidic compounds were eluted from the Dowex 1 column with $6 \mathrm{M}$-formic acid, and further fractionated by paper electrophoresis at $\mathrm{pH}$ 4. Three radioactive fractions were isolated, which appeared to be homogeneous, as no further separation occurred on fractionation by paper chromatography in butyl formate-formic acid-water $(10: 4: 1$, by vol.) (Blundstone, 1963), followed by paper electrophoresis in collidine acetate buffer, pH 7 (Newton \& Abraham, 1954). One of these compounds, which had $R_{F} 0$ on paper chromatography in the solvent mentioned above, was suspected of being ATP. This conclusion was supported by the following experiment.

Two ox lenses were incubated, each in $5 \mathrm{ml}$. of medium A containing $10 \mu \mathrm{C}$ of $\left[2 .{ }^{14} \mathrm{C}\right]$ glycine, for $22 \mathrm{hr}$. The cortices were removed, united $(2 \cdot 2 \mathrm{~g}$. $)$ and ground with $20 \mathrm{ml}$. of cooled $0 \cdot 25 \mathrm{~N}$-perchloric acid. After centrifuging the supernatant was treated with $0.4 \mathrm{ml}$. of a $10 \%(\mathrm{w} / \mathrm{v})$ suspension of acid-washed Norit, the mixture stored for $15 \mathrm{~min}$., and Norit collected by centrifuging, and washed twice with water, and then eluted with $1 \mathrm{ml}$. of $10 \%(\mathrm{v} / \mathrm{v})$ pyridine at $35^{\circ}$. A portion $(0.2 \mathrm{ml}$.) of the eluate was applied as ten $20 \mu \mathrm{l}$. spots (with

Table 4. Radioactive metabolites of $\left[2{ }^{14} \mathrm{C}\right]$ glycine in ox lens

The extent of the incorporation of radioactivity into the compounds listed was determined after incubation of the lenses for $23 \mathrm{hr}$. For details of analytical procedures, see Methods section. The figures given in the last column are percentages of the total radioactivity accounted for by the seven spots; both sides of the paper were counted, and both figures are given. The totals were $46 \cdot 7$ and $47 \cdot 7$ counts/ sec.

\begin{tabular}{cl}
$\begin{array}{c}\text { Spot } \\
\text { no. }\end{array}$ & \multicolumn{1}{c}{ Compound } \\
1 & $\begin{array}{c}\text { Sulphonic acid }\left(\mathrm{GSO}_{3} \mathrm{H}\right) \\
\text { from glutathione }\end{array}$ \\
$\mathbf{2}$ & Glycine \\
$\mathbf{3}$ & Serine \\
$\mathbf{4}$ & Ophthalmic acid \\
$\mathbf{5}$ & Norophthalmic acid \\
$\mathbf{6}$ & Unknown \\
$\mathbf{7}$ & Unknown
\end{tabular}

Extent of incorporation (\%)

45,41

32, 35

7,8

6,6

1, 1

4, 4

5,5 
drying between each application) to no. $3 \mathrm{MM}$ paper and fractionated in the systems (isobutyric acid-ammonia, followed by ammonium sulphate soln.) of Tsuboi \& Price (1959). The most prominent of the spots that absorbed in the ultraviolet $(254 \mathrm{~m} \mu)$ (i.e. quenched the background fluorescence of the paper) was identified as ATP by comparison with markers. Radioautography showed this spot to be radioactive. The incorporation into ATP only amounted to about $0.01 \%$ of the radioactivity in the perchloric acid supernatant. Some of the labelled glutathione was also adsorbed on the charcoal, but this was separated during the chromatography. Electrophoresis in the formic acid-acetic acid buffer was also used to separate GSSG from ATP.

An acidic compound, present at a relatively high concentration, incorporated radioactivity to a small extent. This compound could be lactic acid from its $R_{F}$ in the butyl formate system. Since radioactive lactic acid is present in the medium after incubation of ox lens with $\left[2{ }^{14} \mathrm{C}\right]$ glycine (R. van Heyningen, personal communication), the lactic acid in the lens will also be labelled.

Conversion of glycine into glyoxylic acid. A dispersion of ox lens cortex was incubated with $1 \cdot 25 \mu \mathrm{C}$ of $\left[2{ }^{14} \mathrm{C}\right]$ glycine and $10 \mu$ moles of potassium glyoxylate for $5 \mathrm{hr}$. at $36^{\circ}$. Carrier glyoxylic acid ( $1 \mathrm{~m}$-mole) was then added, and the glyoxylic acid isolated as its dinitrophenylhydrazone, and recrystallized to constant specific activity. The specific activity was about $0.01 \%$ of that of the added glycine (after allowing for the dilution by the carrier); the conversion of glycine into glyoxylate thus occurs only to a small extent.

In a similar experiment in which $\mathrm{N}$-formylglutamate was present during the incubation, little or no radioactivity was incorporated into the formylglutamate.

\section{DISCUSSION}

\section{Incorporation of amino acids into proteins of the lens}

Both experimental and theoretical difficulties attend the study of the incorporation of radioactive amino acids into proteins. The experimental difficulties lie in the removal of highly active contaminants from the protein. The theoretical difficulties lie in the interpretation of the kinetic parameters. The separation of protein from amino acids was accomplished by gel filtration, which is more effective than precipitation of the protein. Neither method separates protein from amino acylRNA. This separation may be carried out by dissolving the protein in alkali, and, after an interval, reprecipitating it with trichloroacetic acid. This step has a marked effect on the specific activity of the proteins in the nucleus of ox lens (Table 1), but little or no effect in experiments in which incorporation into the proteins of the whole ox (or calf) lens was measured.

The calculated curve shown in Fig. 1 was based on equation (2); if B were homogeneous, $\lambda$ would give the fraction of protein formed per hour; thus, in an ox lens (containing about $700 \mathrm{mg}$. of protein), the rate of protein synthesis would be $700 \lambda \mathrm{mg} . / \mathrm{hr}$. It will now be shown that this may be approximately true for the mixture of proteins that was used.

Consider (for the sake of simplicity) just two proteins, B and C, formed from A:

$$
\mathrm{A} \underset{v_{-1}}{\stackrel{v_{1}}{\rightleftharpoons}} \mathrm{B} \quad \mathrm{A} \underset{v_{-2}}{\stackrel{v_{2}}{\rightleftharpoons}} \mathrm{C}
$$

The amounts of $\mathrm{B}$ and $\mathrm{C}$ are written as $b, c$; the (relatively small) amounts of labelled $\mathrm{B}$ and $\mathrm{C}$ as $b^{\mathrm{x}}, c^{\mathrm{x}}$; the specific activities as $S_{\mathrm{B}}=b^{\mathrm{x}} / b, S_{\mathrm{C}}=c^{\mathrm{x}} / c$. The measured specific activity $(S)$ of the mixture is

$$
S=\left(b^{\mathbf{x}}+c^{\mathbf{x}}\right) /(b+c)=\left(b S_{\mathrm{B}}+c S_{\mathrm{C}}\right) /(b+c)
$$

i.e. the measured specific activity is the weighted mean of the specific activities of the components. Since

$$
\begin{gathered}
b^{\mathbf{x}}+c^{\mathbf{x}}=S(b+c) \\
\mathrm{d} b^{\mathbf{x}} / \mathrm{d} t+\mathrm{d} c^{\mathbf{x}} / \mathrm{d} t=\mathrm{d} S / \mathrm{d} t(b+c)+S(\mathrm{~d} b / \mathrm{d} t+\mathrm{d} c / \mathrm{d} t) \\
(b+c) \mathrm{d} S / \mathrm{d} t=v_{1} S_{\mathrm{A}}-v_{-1} S_{\mathrm{B}} \\
+v_{2} S_{\mathrm{A}}-v_{-2} S_{\mathrm{C}}-S\left(v_{1}-v_{-1}+v_{2}-v_{2}\right)
\end{gathered}
$$

i.e.

$$
\begin{aligned}
(b+c) \mathrm{d} S / \mathrm{d} t=\left(v_{1}+v_{2}\right)\left(S_{\mathrm{A}}-S\right)+ & v_{-1}\left(S-S_{\mathrm{B}}\right) \\
& +v_{-2}\left(S-S_{\mathrm{C}}\right)
\end{aligned}
$$

Now the second and third terms on the right-hand side of equation (4) involve the specific activities of the proteins and, as a first approximation, it is reasonable to neglect these terms since (in the experiments described) the specific activity of the protein was less than one-thousandth of that of the amino acids; it seems unlikely that the specific activity of any individual protein will be so different from the mean, and $v_{-1}, v_{-2}$ will not differ by as much since any particularly labile protein will be present in relatively low amount. Thus, if all the terms involving the specific activities of proteins may be ignored:

and

$$
(b+c) \mathrm{d} S / \mathrm{d} t=\left(v_{1}+v_{2}\right) S_{\mathrm{A}}
$$

$$
\lambda=\left(v_{1}+v_{2}\right) /(b+c)=\left(\lambda_{\mathrm{B}} b+\lambda_{c} c\right) /(b+c)
$$

Thus the parameter $\lambda$ (like the specific activity) is a weighted mean, and the rate of protein synthesis calculated from the data is approximately the sum of the rates of synthesis of the individual proteins. Jardetzky \& Barnum (1958) considered a heterogeneous system (e.g. cells of different types) rather than a mixture of proteins, and showed that the 
rate obtained from isotopic data was an upper limit to the true rate.

The rate of protein synthesis $\left(v_{5}\right)$ in ox lens, then, is approximately $700 \lambda$, i.e. about $0.06 \mathrm{mg}$. $/ \mathrm{hr}$. The rate of net synthesis, due to growth, is about $0.01 \mathrm{mg} . / \mathrm{hr}$. in the living animal (Krause, 1934; François \& Rabaey, 1957). Thus in the scheme:

$$
\begin{gathered}
\text { amino acids } \stackrel{\stackrel{\text { synthesis }}{\longrightarrow} \text { proteins } \stackrel{\text { breakdown }}{v_{5}} \text { amino acids }}{v_{6}} \text { amo. } \\
v_{5}-v_{6}=0.01, \quad v_{5}=0.06, \quad v_{6}=0.05 .
\end{gathered}
$$

According to the definition of Reiner (1953), the turnover rate of ox lens protein is then $0.05 \mathrm{mg}$. $/ \mathrm{hr}$. The rate $v_{5}$ includes the rate of synthesis by the reverse of proteolysis (Reiner, 1963), but this will presumably be a small fraction of the rate of breakdown $\left(v_{6}\right)$ (and therefore negligible) as the reaction (proteolysis) is far from equilibrium. The measured rate of protein breakdown was somewhat higher, about $0.15 \mathrm{mg} . / \mathrm{hr}$. (Waley \& van Heyningen, 1962), in diluted, dialysed lens dispersions; this difference may be due to the higher ionic strength in the cell, since the rate of proteolysis was decreased by raising the ionic strength. There is little or no net breakdown of protein during the incubations, since one ox lens contained $40 \mu$ moles of amino compounds (as leucine equivalents, by the ninhydrin reaction) before incubation, and the pair lens contained $42 \mu$ moles after incubation for $22 \mathrm{hr}$. in medium $A$. The rate of protein synthesis in ox lens given above is about $1 \%$ of the value calculated for the proteins of rat liver (Loftfield \& Eigner, 1958; Swick, 1958). The values given for rabbit lens in vitro (Merriam \& Kinsey, 1950) and in vivo (Weber, 1961) apparently refer to rates of incorporation rather than to rates of reaction.

The low extent of incorporation into the proteins of the nucleus of ox lens (Table 1) parallels results obtained with rabbit lens (Frohman \& Kinsey, 1952). The comparable extents of incorporation into the proteins precipitated at $\mathrm{pH} 5$ ( $\alpha$-crystallin) and soluble at $\mathrm{pH} 5$ ( $\beta$-crystallin) (Table 2 ) suggest that the rates of synthesis of the proteins in these fractions are not very different. The former $(\alpha-$ crystallin) was the substrate for the neutral proteinase isolated from ox lens (van Heyningen \& Waley, 1963), but protein interactions (and the ionic strength) were different in the intact lens from what they were under the conditions of assay.

Puromycin in the incubation medium inhibited the incorporation of radioactive valine into calf lens protein (Table 3), as is found with other cells (Rabinowitz \& Fisher, 1962; Allen \& Schweet, 1962). There was, however, no evidence for the accumulation of appreciable quantities of radioactive oligopeptides either free or bound to RNA. The concentrations of activated amino acids in tissues may be very low, e.g. $10^{-10} \mathrm{~mole} / \mathrm{g}$. of tissue
(Loftfield, Eigner \& Hecht, 1958), and peptides present at this concentration would be difficult to detect.

\section{Catabolism of valine in lens}

Valine belongs to the category of essential amino acids that can be oxidized in tissues other than liver (Miller, 1962), and the present identification of glutamic acid (and glutathione) as metabolites of valine shows that the lens has the capacity to use amino acids as a source of energy. The metabolic pathway (by analogy with other tissues) is that valine is converted into propionate (Greenberg, 1961) and propionate is converted into succinate by carboxylation and isomerization (Raafat, Verbeke \& Peeters, 1963). The glutamate is then formed from succinyl-coenzyme $A$, via the citric acid cycle, and 2-oxoglutarate. Similarly, pyruvate is converted into glutamate in the lens (Kinoshita \& Merola, 1961).

\section{Metabolism of glycine}

The metabolic pathways inferred from incubations of ox lens with $\left[2-{ }^{-14} \mathrm{C}\right]$ glycine are shown in Scheme 1.

The conversion of glycine into glutathione and into serine (reactions that commonly occur in animal cells) had been observed in rabbit lens (Kinsey \& Merriam, 1950; Merriam \& Kinsey, 1950). The incorporation of glycine into the analogues of glutathione (ophthalmic acid and norophthalmic acid) in the intact lens confirms the pathways previously postulated from experiments with lens extracts (Cliffe \& Waley, 1958). The extents of incorporation of radioactivity into glutathione and its analogues (Table 4) were approximately proportional to their concentrations and so the specific activities of the peptides were com. parable.

Such catabolism of glycine as occurs in animal cells (and it is often relatively slight; Arnstein, 1954) may proceed via serine and thence pyruvate, or via glyoxylate (Greenberg, 1961). Evidence for the former route is provided by the formation of lactate. Glycine was converted into glyoxalate in a dispersion of lens, but the extent of reaction was small. The catabolism of glycine by either route may well be a very minor reaction in ox lens.

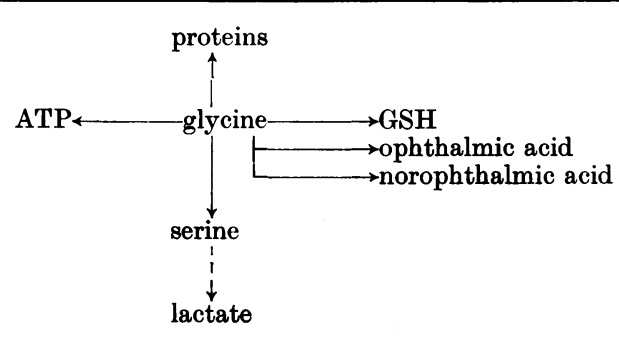

Scheme 1. Metabolism of glycine in ox lens. 
The formation of radioactive ATP from $\left[2-{ }^{14} \mathrm{C}\right]$ glycine represents the only clue to the mode of purine biosynthesis in the lens. Further work is needed to decide whether the purine ring is synthesized (Buchanan \& Hartmann, 1959) in the lens.

\section{SUMMARY}

1. Radioactive glycine was incorporated into the proteins of the cortex of intact ox lens to a much greater extent than into those of the nucleus of the lens.

2. The specific activities of the $\alpha$-crystallin and $\beta$-crystallin fractions were comparable.

3. The kinetics of the incorporation of mixed radioactive amino acids into ox lens protein lead to a calculated value of $0.06 \mathrm{mg}$./ $/ \mathrm{hr}$. for the rate of protein synthesis; growth contributes only $0.01 \mathrm{mg}$./ $\mathrm{hr}$. to this value. These values indicate that protein turnover occurs in the lens.

4. The incorporation of uniformly labelled L-valine into the proteins of calf lens was inhibited by puromycin; the inhibition did not lead to the accumulation of appreciable amounts of radioactive peptides.

5. Catabolism of valine by the lens gave glutamate, glutathione and several unidentified products.

6. Glycine was converted in the lens into glutathione, ophthalmic acid, norophthalmic acid, serine, lactate, adenosine triphosphate and several unidentified products; the extent of incorporation of radioactivity into glutathione was high.

I thank Dr R. van Heyningen for much help with the lens incubations; also $\mathrm{Mr} \mathrm{R}$. Priscott for skilled technical assistance, the National Council to Combat Blindness Inc., New York, for Fight-for-Sight Grants for the purchase of equipment, and the staffs of the Oxford Co-operative Society and Eastwyck Farm Slaughterhouses for their cooperation.

\section{REFERENCES}

Allen, E. H. \& Schweet, R. S. (1962). J. biol. Chem. 237, 760.

Arnstein, H. R. V. (1954). Advanc. Protein Chem. 9, 2.

Blundstone, H. A. W. (1963). Nature, Lond., 197, 377.

Buchanan, J. M. \& Hartmann, S. C. (1959). Advanc. Enzymol. 21, 199.
Cliffe, E. E. \& Waley, S. G. (1958). Biochem. J. 69, 649.

Dardenne, U. \& Kirsten, G. (1962). Exp. Eye Res. 1, 415.

François, J. \& Rabaey, M. (1957). A.M.A. Arch. Ophthal. $57,672$.

Frohman, C. E. \& Kinsey, V. E. (1952). A.M.A. Arch. Ophthal. 48, 12.

Grassmann, W., Hannig, K. \& Plöckl, M. (1955). HoppeSeyl. Z. 299, 258.

Greenberg, D. M. (1961). In Metabolic Pathways, vol. 2, p. 79. Ed. by Greenburg, D. M. New York: Academic Press Inc.

Guggenheim, E. A. (1926). Phil. Mag. 2, 538.

Helmreich, E. \& Kipnis, D. M. (1962). J. biol. Chem. 237, 2582.

Jardetzky, C. D. \& Barnum, C. P. (1958). Arch. Biochem. Biophys. 73, 435.

Kinoshita, J. H. \& Merola, L. O. (1961). Exp. Eye Res. 1, 53.

Kinsey, V. E. \& Merriam, F. C. (1950). A.M.A. Arch. Ophthal. 40, 370.

Krause, A. C. (1934). A.M.A. Arch. Ophthal. 17, 502.

Loftfield, R. B. \& Eigner, E. A. (1958). J. biol. Chem. 231, 925.

Loftfield, R. B., Eigner, E. A. \& Hecht, L. L. (1958). Proc. 4th int. Congr. Biochem., Vienna, vol. 8, p. 222.

Maramatsu, M. \& Busch, H. (1962). Analyt. Biochem. 4, 384.

Merriam, F. C. \& Kinsey, V. E. (1950). A.M.A. Arch. Ophthal. 44, 651.

Miller, L. L. (1962). In Amino Acid Pools, p. 608. Ed. by Holden, J. T. Amsterdam: Elsevier.

Naughton, M. A. \& Hagopian, H. (1962). Analyt. Biochem. 3, 276.

Newton, G. G. F. \& Abraham, E. P. (1954). Biochem. J. 58, 103.

Porath, J. (1960). Biochim. biophys. Acta, 39, 193.

Raafat, M. A., Verbeke, R. \& Peeters, G. (1963). Biochem. J. 88, 155.

Rabinowitz, M. \& Fisher, J. M. (1962). J. biol. Chem. 237, 477.

Reiner, J. M. (1953). Arch. Biochem. Biophys. 46, 80.

Reiner, J. M. (1963). In Advances in Tracer Methodology, p. 210. Ed. by Rothchild, S. New York: Plenum Press.

Swick, R. W. (1958). J. biol. Chem. 231, 751.

Tsuboi, K. K. \& Price, T. D. (1959). Arch. Biochem. Biophys. 81, 224.

Turba, F. \& Esser, H. (1955). Biochem. Z. 327, 93.

van Heyningen, R. \& Waley, S. G. (1963). Biochem. J. 86, 92.

Waley, S. G. (1956). Biochem. J. 64, 715.

Waley, S. G. \& van Heyningen, R. (1962). Biochem. J. 83, 274.

Weber, D. (1961). Ber. Versamm. dtsch. ophthal. Ges. 64, 296. 